\title{
Centroblastic Lymphoma
}

National Cancer Institute

\section{Source}

National Cancer Institute. Centroblastic Lymphoma. NCI Thesaurus. Code C4074.

A B-cell non-Hodgkin lymphoma composed of large noncleaved cells. This is a subtype of diffuse large B-cell non-Hodgkin lymphoma. 